\title{
Morphology of the tropopause layer and lower stratosphere above a tropical cyclone: a case study on cyclone Davina (1999)
}

\author{
F. Cairo ${ }^{1}$, C. Buontempo ${ }^{1, *}$, A. R. MacKenzie ${ }^{2}$, C. Schiller ${ }^{3}$, C. M. Volk ${ }^{4}$, A. Adriani ${ }^{1, * *}$, V. Mitev ${ }^{5}$, R. Matthey ${ }^{5}$, \\ G. Di Donfrancesco $^{6}$, A. Oulanovsky ${ }^{7}$, F. Ravegnani ${ }^{1}$, V. Yushkov ${ }^{7}$, M. Snels $^{1}$, C. Cagnazzo $^{8}$, and L. Stefanutti ${ }^{9},{ }^{* * * *}$ \\ ${ }^{1}$ Istituto di Scienze dell'Atmosfera e del Clima, CNR, Roma, Italy \\ ${ }^{2}$ Environmental Science Department, Lancaster University, Lancaster, UK \\ ${ }^{3}$ Institute for Stratospheric Research, Forschungszentrum Jülich GmbH, Jülich, Germany \\ ${ }^{4}$ Institute for Atmosphere and Environment, J. W. Goethe University, Frankfurt, Germany \\ ${ }^{5}$ Observatoire Cantonal Neuchatel, Neuchatel, Switzerland \\ ${ }^{6}$ Ente per le Nuove Tecnologie, l'Energia e l'Ambiente, Frascati, Rome, Italy \\ ${ }^{7}$ Central Aerological Observatory, Dolgoprudny, Russia \\ ${ }^{8}$ Istituto Nazionale di Geofisica e Vulcanologia, Boulogne, Italy \\ ${ }^{9}$ Airborne Platform for earth Observation, Comitato di Gestione, Florence, Italy \\ * now at: United Kingdom Meteorological Office, Exeter, UK \\ *** now at: Istituto di Fisica dello Spazio Interplanetario, INAF, Rome, Italy \\ *** now at: Geophysica Gruppo Europeo di Interesse Economico, Florence, Italy
}

Received: 14 November 2007 - Published in Atmos. Chem. Phys. Discuss.: 21 December 2007

Revised: 28 March 2008 - Accepted: 2 June 2008 - Published: 1 July 2008

\begin{abstract}
During the APE-THESEO mission in the Indian Ocean the Myasishchev Design Bureau stratospheric research aircraft M55 Geophysica performed a flight over and within the inner core region of tropical cyclone Davina. Measurements of total water, water vapour, temperature, aerosol backscattering, ozone and tracers were made and are discussed here in comparison with the averages of those quantities acquired during the campaign time frame.

Temperature anomalies in the tropical tropopause layer (TTL), warmer than average in the lower part and colder than average in the upper TTL were observed. Ozone was strongly reduced compared to its average value, and thick cirrus decks were present up to the cold point, sometimes topped by a layer of very dry air. Evidence for meridional transport of trace gases in the stratosphere above the cyclone was observed and perturbed water distribution in the TTL was documented. The paper discuss possible processes of dehydration induced by the cirrus forming above the cyclone, and change in the chemical tracer and water distribution in the lower stratosphere $400-430 \mathrm{~K}$ due to meridional transport from the mid-latitudes and link with Davina. Moreover it compares the data prior and after the cyclone passage to discuss its actual impact on the atmospheric chemistry and thermodynamics.
\end{abstract}

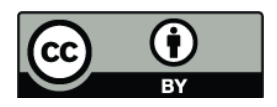

Correspondence to: F. Cairo (f.cairo@isac.cnr.it)

\section{Introduction}

The amount of water vapour and trace gases present in the uppermost part of the tropical troposphere is an important parameter to quantify because it is mainly from that region that air enters the stratosphere, where water vapour plays a major role in regulating chemistry and temperatures (Holton et al., 1995). For instance, water vapour in the stratosphere is involved both in the production of the important $\mathrm{OH}$ hydroxyl radicals and in the formation of polar stratospheric clouds which subsequently help to destroy ozone (Kirk-Davidoff, 1999). Understanding the balance of processes that govern the exchange of air across the tropical tropopause is thus a major priority for stratospheric meteorology and Earth system science. It has long been recognized that as air passes the tropical tropopause it dehydrates to a value approximately equal to the value of the saturation vapour mixing ratio dictated by the cold temperature of the tropical tropopause (Brewer, 1949). However, the processes that decide exactly how much water vapor stays in the air, and how much is removed by condensation and sedimentation processes, are still under debate. Several processes on different time scales may affect the exchange of air between the stratosphere and the troposphere in the tropics. In particular, the balance between the slow tropical upwelling driven by the Brewer-Dobson circulation and the rapid upwelling in deep convection is not well known (Dessler, 2002; Danielsen, 1982). Although

Published by Copernicus Publications on behalf of the European Geosciences Union. 
in the upper tropical troposphere dehydration and vertical movement into the stratosphere need not be linked, at least on small timescales, and horizontal advection seems to play the major role in the dehydration (Fueglistaler et al., 2004; Holton and Gettelman, 2001), evaluating the impact of organized convection on the tropical upper troposphere is still crucial.

In recent years, the study of the upper tropical troposphere developed the concept of a tropical tropopause layer (TTL) (Atticks and Robinson 1983; Highwood and Hoskins, 1998), as a border region between the convective-radiative equilibrium of the troposphere and the radiative equilibrium of the stratosphere. In this transition zone both stratospheric and tropospheric processes interact. In the troposphere below approximately 14 the radiative cooling is balanced by latent heat release by convection, while above approximately $16 \mathrm{~km}$ the radiative heating balances the stratosphere-driven upwelling. Cumulus tops are rarely observed above $14 \mathrm{~km}$, and this implies an abrupt reduction of convective mass flux above that level. The ozone concentration starts to increase there well below the cold point tropopause (Folkins et al., 1999; Fujiwara et al., 2000; Mackenzie et al., 2006; Vaughan et al., 2008) and the lapse rate starts to move away from the moist adiabatic below $14 \mathrm{~km}$ (Folkins and Braun, 2001). In the lower part of the TTL a mixing barrier exists (Folkins et al., 1999; Folkins et al., 2000) so that the residence time of air in the TTL is greater than in any other level of the troposphere. In fact, following Gettelman et al. (2002), the probability that a convective cloud penetrates the TTL above $14 \mathrm{~km}$ is about $1 \%$, this estimate only slightly increased by Alcala and Dessler (2002) using satellite data.

Part of the deep convection in the tropics occurs in the organized structure of cyclones. In fact, the cumulus convection associated with the central part of a tropical cyclone is probably the most organized form of convection present in the tropics and its effect on the upper troposphere and lower stratosphere may reflect this collective behaviour. This self organization is responsible for the extreme temperature reached in the core (warm anomalies) and in the lower stratosphere overlaying the eye of the storm (cold anomalies). The coldest cloud top temperatures ever recorded were associated directly or indirectly to cyclone convection (Ebert and Holland, 1991). Furthermore during the developing stage of a tropical cyclone deep overshooting around the eye wall is very likely to occur. The lifetime and size of cyclones also implies that their impact on the TTL could be significant on the regional scale.

The present paper addresses the effects of tropical cyclones on the upper tropical troposphere and lower stratosphere. We present and discuss observations taken in the TTL and lower stratosphere in and above a tropical cyclone, by the instrumented research aircraft Geophysica during the tropical campaign of the Airborne Platform for Earth observations - THird European Stratospheric Experiment on Ozone (APE-THESEO) project, in 1999. In particular we look for evidence of (i) downward transport of stratospheric air, (ii) upward transport of marine boundary layer air, and (iii) cloud-induced changes to the water content of air throughout the TTL.

The purpose of APE-THESEO was to study the microphysical processes in tropical cirrus and the transport of tracers both across the tropopause and in the lower stratosphere. The field campaign was carried out from the International Airport of Mahè, Seychelles $\left(4^{\circ} 42^{\prime} \mathrm{S}, 55^{\circ} 30^{\prime} \mathrm{E}\right)$ from 15 February to 15 March 1999, and two research aircraft were deployed: the DLR Falcon 20 and the M-55 Geophysica. The DLR Falcon, equipped with the OLEX LIDAR, acted as a pathfinder for the stratospheric airplane, while the Geophysica acquired in-situ data on water substance and trace gases at higher levels. A review of the activities during the campaign can be found in Stefanutti et al. (2004).

The campaign comprised seven local flights from Mahè, covering the region of the South-western Indian Ocean. One of the seven local flights - on 9 March 1999 - was devoted to sample the TTL above the tropical cyclone Davina, off the coast of La Reunion island in the southern Indian Ocean.

The present work is organized as follows: Sect. 2 presents a review of what is known about the influence of cyclones on the upper troposphere and lower stratosphere (UTLS). Section 3 describes the instruments, data and methods that will be used in subsequent analysis. Section 4 presents the meteorological situation at the time of the flight, and the data acquired during the M55 flight over the cyclone, in comparison with the averages acquired in the timeframe of the campaign. In Sect. 5 the observations will be discussed. Section 6 draws conclusions from our study.

\section{Cyclones in the UTLS}

A general analysis of cyclone organization, behaviour and climatology is beyond the scope of this work, and we address the interested reader to the review of Emanuel (2003) and references therein. Here our attention is focussed on what is known on the structure and effects of cyclones on the UTLS.

The general characteristics of the UTLS above the cyclone are the following (Koteswaram, 1967): the low pressure core extends throughout the troposphere and into the stratosphere, although the horizontal pressure gradient rapidly decreases with height. Winds, which are cyclonic throughout most of the volume occupied by the cyclone, reverse their sense of rotation near the top of the storm, often losing their axial symmetry and becoming concentrated in some "outflow jets" that curve anticyclonically from the storm core. The upper level outflows ultimately lead to the formation of an extended cirrus deck capping the cyclone, with more elevated clouds close to the eyewall, higher at the front of the cyclone and lower at the rear (Kovacs and McCormick, 2003), and cloud tops decreasing radially outward in a sort of umbrella-shaped shield. 
Often, but not always, the lower level warm core gives way to a cold core above $15 \mathrm{~km}$, so that highest and lowest temperature anomalies occur at $8-12 \mathrm{~km}$ and near the tropopause, respectively. Rings of warm and cold air extend radially from the tropopause above the cyclone core, which is colder than average and generally bulged upward. While in the upper troposphere the isentropes are curved downward toward the centre of the cyclone, in the lower stratosphere isentropes radially undulate from it and are curved upward from the centre of the cyclone. In the tropopause region above the core, therefore, the vertical gradient of potential temperature is reduced. The cold temperature anomaly extends above the tropopause but weakens quickly with height, relaxing in $1-2 \mathrm{~km}$ to the average temperature profile (Waco, 1970).

A good indicator of air-mass redistribution and exchanges in and over cyclones are the perturbations in the ozone field. Measurements of upper level ozone in cyclones started in the sixties with the reconnaissance flights of the stratospheric aircraft U2. Penn (1965) showed increased values of ozone in the upper troposphere, from the cloud tops situated at $200 \mathrm{hPa}$ up to the tropopause level, on the weak Ginny cyclone. The same author (Penn, 1966) showed no significant variation in ozone mixing ratio in the lower stratosphere down to the tropopause level above the Isbell cyclone core.

In 1991 the DC-8 sampled the Typhoon Mireille from the boundary layer to the upper troposphere up to $12 \mathrm{~km}$ (Newell et al., 1996); the boundary layer eye region showed increased levels of ozone but at higher levels there was no evidence from ozone lidar cross sections - of increased ozone from downward entrainment of stratospheric air into the eye upper region; this indeed showed low tropospheric values.

The absence of significant stratospheric mixing above the cyclone's eye was also reported by Carsey and Willoughby (2005) who reported low concentrations of ozone in the eyes of hurricanes Georges and Floyd. There, significant variations of tropospheric ozone mixing ratio between $2 \mathrm{~km}$ and $6 \mathrm{~km}$, between the intensifying and weakening regimes of the storms, were reported. During intensification, ozone values indicated only a small descent of air from above flight level, topping at $6 \mathrm{~km}$, or a dilution with low-ozone eyewall air. During weakening, ozone concentrations were low throughout the eye and eyewall, consistent with the eyes being filled with boundary layer air. Regions of warm, dry, ozone-rich air that were attributed to mesoscale downdraft, were also detected, but detached from the eye region. This finding of possible stratospheric injection in proximity of cyclones substantiated earlier work of Baray et al. (1999) that suggested mesoscale transport of air-masses by strong ageostrophic movements around the cyclone convective area. This suggestion has been supported by mesoscale modelizations (Leclair De Bellevue et al., 2007) while another study showed that this kind of event is not exceptional in the Indian Ocean basin (Leclair De Bellevue et al., 2006).
Ozone distributions in cyclones have also been studied with the aid of satellites. A study of Zou and Wu (2005) shows that variations of column ozone levels are linked to the stages of formation, intensification and movement of a hurricane. They analyzed ozone levels in 12 hurricanes and found that the area of a hurricane has typically low levels of ozone from the surface to its top. When the storm intensifies, the ozone levels throughout the storm decrease. Moreover they discovered that ozone levels - although lower than in the unperturbed troposphere - are elevated in the eye region of tropical cyclones relative to the area outside the eye, probably due to intrusions of stratospheric air. This latter effect, which contrasts with many aircraft measurements, has been questioned by Joiner et al. (2006) who pointed to an incorrect estimation of cloud top pressures in the retrieval of TOVs total column ozone, as a cause of this effect. Stratospheric intrusion indeed occur, but displaced from the cloud-defined eye.

Water vapour and ozone distributions over hurricane Floyd were also studied by Richard et al. (2001), who reported lower water vapour, lower ozone and higher methane mixing ratios during the Floyd overflight between the tropopause and $80 \mathrm{mb}(18 \mathrm{~km})$, prompting the authors to suggest that local dehydration was occurring right above the storm, while the lower ozone and higher methane indicated upward transport of tropospheric air. The issue of tropical cyclones as sites of active dehydration of tropospheric air entering the stratosphere was addressed in the paper of Danielsen (1993), who, in an analysis of a flight conducted from Darwin, Australia, over cyclone Damien showed that the deep convection induced by the cyclone resulted in clouds upwelling and in a more pronounced elevation of the tropopause. Large thermal inversions were observed above the cold point - analogously to the observations by Waco (1970) - where any vertical velocity difference would easily promote internal gravity waves, ultimately producing turbulence and diffusive vertical transport. This rapid vertical transport episode was also documented by Radon measurements by Kritz et al. (1993).

A schematic diagram of the salient features documented in the literature reviewed above is presented in Table 1 .

The organized character of cyclones and the large scale modifications that they induce in the UTLS, which may reach a length scale of $3000 \mathrm{~km}$ in the upper troposphere (Merrill, 1988), are suggestive of a distinctive effect they might have on the TTL, different from that of unorganized deep convection in the tropics. For instance, we may note that the peculiar temperature structure of the UTLS above cyclones, i.e. colder and less stable than the mean background TTL profile, is well suited to test the convective-dehydration mechanisms (Teitelbaum et al., 2000; Vomel et al., 1995; Danielsen, 1982). The air that dries to low mixing ratios as it ascends within deep convective towers, may enter the stratosphere when the tropopause is higher and colder than average, so that the stratosphere would be drier than the minimum saturation mixing ratio from an average tropical temperature profile. 
Table 1. Schematic of the main results reviewed in the literature about cyclones' influence on Upper Troposphere - Lower Stratosphere.

\begin{tabular}{|c|c|c|}
\hline Authors, Year & Main Topic & Highlight \\
\hline Koteswaram (1967) & $\begin{array}{l}\text { Thermal and dynamical structure of cy- } \\
\text { clones in the upper troposphere and lower } \\
\text { stratosphere. }\end{array}$ & $\begin{array}{l}\text { Cold core above } 15 \mathrm{~km} \text {. Presence of peripheral ridge } \\
\text { and outflows jets close to the tropopause. }\end{array}$ \\
\hline Kowacs and McCormick (2003) & $\begin{array}{l}\text { Vertical profiling of clouds and aerosols } \\
\text { from space (LITE) through a cross section } \\
\text { of Typhoon Melissa. }\end{array}$ & $\begin{array}{l}\text { Cirrus shield of a tropical cyclone approximately } 5 \mathrm{~km} \\
\text { thick, extending } 4000 \mathrm{~km} \text { between the center of circula- } \\
\text { tion and the equator. }\end{array}$ \\
\hline Waco (1970) & $\begin{array}{l}\text { Horizontal and vertical temperature struc- } \\
\text { ture. }\end{array}$ & $\begin{array}{l}\text { Location of a very cold tropopause just above the cloud } \\
\text { tops; Large vertical temperature gradient above the } \\
\text { tropopause; Small horizontal temperature fluctuations }\end{array}$ \\
\hline Penn (1965) & $\begin{array}{l}\text { Temperature and Ozone measurements in } \\
\text { a hurricane. }\end{array}$ & $\begin{array}{l}\text { Ozone-rich UTLS above cloud tops. Above the } \\
\text { tropopause over the eye, air warmer and considerably } \\
\text { richer ozone. }\end{array}$ \\
\hline Penn (1966) & $\begin{array}{l}\text { Temperature and Ozone measurements in } \\
\text { a hurricane. }\end{array}$ & $\begin{array}{l}\text { The tropopause inclined upwards toward the eye; Above } \\
\text { the tropopause no significant variation in ozone. }\end{array}$ \\
\hline Newell et al. (1996) & $\begin{array}{l}\text { Typhoon redistribution of trace con- } \\
\text { stituents, importance on the global scale. }\end{array}$ & $\begin{array}{l}\text { No evidence of ozone for the downward entrainment of } \\
\text { stratospheric air into the eye region; substantial entrain- } \\
\text { ment of boundary layer air into the eye wall region. }\end{array}$ \\
\hline Carsey and Willoughby (2005) & $\begin{array}{l}\text { Temperature and Ozone measurements in } \\
\text { hurricanes. }\end{array}$ & $\begin{array}{l}\text { Marked changes between the intensifying and weak- } \\
\text { ening stages During intensification, tropospheric ozone } \\
\text { levels indicated descent of air in the periphery, or dilu- } \\
\text { tion with low-O3 eyewall air. During weakening, ozone } \\
\text { concentrations were low throughout the eye and eye- } \\
\text { wall. }\end{array}$ \\
\hline Baray et al. (1999) & $\begin{array}{l}\text { Stratosphere-troposphere exchange in a } \\
\text { tropical cyclone }\end{array}$ & $\begin{array}{l}\text { Transfer of ozone from the stratosphere to the mid- } \\
\text { troposphere; Pumping of ozone-poor air masses from } \\
\text { the boundary layer to the upper troposphere. }\end{array}$ \\
\hline Leclair de Bellevue (2007) & $\begin{array}{l}\text { Mesoscale modelization of Stratosphere- } \\
\text { troposphere exchange in a cyclone }\end{array}$ & $\begin{array}{l}\text { Stratospheric injection in divergence zones in the tropo- } \\
\text { sphere }\end{array}$ \\
\hline Leclair de Bellevue (2006) & $\begin{array}{l}\text { Climatology of tropospheric ozone pro- } \\
\text { files associated with tropical convection } \\
\text { and cyclones. }\end{array}$ & $\begin{array}{l}\text { Transfer of ozone from the stratosphere to the mid- } \\
\text { troposphere; Pumping of ozone-poor air masses from } \\
\text { the boundary layer to the upper troposphere. }\end{array}$ \\
\hline Zou and $\mathrm{Wu}(2005)$ & $\begin{array}{l}\text { Satellite column ozone measurements } \\
\text { over hurricanes }\end{array}$ & $\begin{array}{l}\text { Variations of total ozone amounts are closely linked to } \\
\text { the life stage of a hurricane. Stratospheric intrusions in } \\
\text { the eye regions are likely. }\end{array}$ \\
\hline Joiner et al. (2006) & $\begin{array}{l}\text { Satellite column ozone measurements } \\
\text { over hurricanes }\end{array}$ & $\begin{array}{l}\text { Small amounts of stratospheric intrusion into the eye re- } \\
\text { gion. }\end{array}$ \\
\hline Richard et al. (2001) & $\begin{array}{l}\text { Troposphere-Stratosphere transport and } \\
\text { dehydration in cyclones }\end{array}$ & $\begin{array}{l}\text { Low water vapour and ozone and high methane in the } \\
\text { lower stratosphere above a cyclone. Local dehydration } \\
\text { and upward transport of ozone poor and methane rich } \\
\text { tropospheric air. }\end{array}$ \\
\hline Danielsen (1993) & $\begin{array}{l}\text { Troposphere-Stratosphere transport and } \\
\text { dehydration in cyclones }\end{array}$ & $\begin{array}{l}\text { Large scale upwelling and dehydration in cirrus shield } \\
\text { above cyclone }\end{array}$ \\
\hline Kritz et al. (1993) & $\begin{array}{l}\text { Troposphere-Stratosphere transport and } \\
\text { dehydration in cyclones }\end{array}$ & Dehydration in cirrus shield above cyclone \\
\hline Merrill et al. (1988) & $\begin{array}{l}\text { Upper-tropospheric flows around hurri- } \\
\text { canes }\end{array}$ & Influence at synoptic scale \\
\hline
\end{tabular}

To evaluate the relative importance of tropical cyclones as preferred regions of convective overshooting, penetrating the TTL or even above the tropopause, we have used the dataset of the Tropical Rainfall Measurements Mission (TRMM) for the year 1999. TRMM measures cloud-top altitude and rain- fall characteristics (Cecil et al., 2005), see Sect. 3 hereafter. This valuable dataset has been already used by Alcala and Dessler (2002) to assess the general impact of tropical convection upon stratospheric dehydration. The process followed for these measurements closely mirror the one adopted 
by Alcala and Dessler in their work: similarly to them we used $14 \mathrm{~km}$ as a proxy for the lower boundary of the TTL. Although this can be considered an arbitrary choice it provides a reasonable threshold to evaluate the penetration of deep convection in the upper tropical troposphere. An estimate of the altitude uncertainty of the TRIMM products can be deduced considering that the minimum vertical resolution of this dataset is $250 \mathrm{~m}$ at nadir.

The TRMM tropical cyclone database available through the Japan Aerospace Exploration Agency (http://www.eorc. jaxa.jp/TRMM/typhoon/index_e.htm), allowed us to evaluate the fraction of the convection associated with tropical cyclones with respect to the overall convection present in the tropical area.

We have used the 2A23 product of the TRMM. In this type of dataset, files store the observations obtained by the Precipitation Radar on board of the satellite. In particular we have used the "rain type" and the "cloud top" products. We have defined as overshooting any pixel of the radar image that was associated with a convective type of rain and, at the same time, showed a cloud top above $14 \mathrm{~km}$, a level usually considered as a good proxy for the lower edge of the TTL (Sherwood and Dessler, 2001).

In this way we have calculated the fraction of the overall cyclone-related convection that is penetrating the TTL. This fraction is close to $3.5 \%$, a value near the one obtained by Alcala and Dessler (2002) for the overall convection in the tropics. This seems to indicate that cyclone associated convection is not in general a preferred pathway for TTL penetration.

Nevertheless, tropical cyclones can still play a preferred role in the water budget of the TTL by providing large areas of relative high clouds, where the thermal effect associated with this cloud deck can be of importance. Moreover, in some stage of the cyclone life cycle the overshooting could still lead to more frequent and deeper injection into the TTL. A work by Kelley and Stout (2004) subdivided the TRMM cyclone observations with respect to their life stage, and clearly showed that in the cyclone intensification stage, convective towers are more than twice as likely to occur as in the other stages, and that these towers reach higher than at other stages.

However, previous direct in-situ observations documenting the effects of cyclones on the TTL and the LS are too sparse to draw definite conclusions.

\section{Instruments and methods}

We compare the profiles of meteorological parameters (water, clouds, ozone and tracers) detected in and over the cyclone Davina with the average profiles acquired during the time frame of the APE-THESEO field campaign. The general meteorological setting for the campaign is given in Stefanutti et al. (2004). An analysis of the temperature, ozone, clouds and water vapour profiles acquired during the campaign has been reported in MacKenzie et al. (2006). In the present work the focus is on the specific effects of tropical cyclones on the UTLS.

A short introduction to the encounter with cyclone Davina described below, has been published in the Royal Meteorological Society's Weather magazine (Buontempo et al., 2006); in that work, lidar data from the Falcom F-20 are compared to idealized cyclone structure as predicted by the model of Emanuel (1999).

In the following sections we describe briefly the instruments deployed during the flight and the satellite data we used to interpret the meteorological situation.

\subsection{The M55 payload}

Aerosol and cloud detection at the aircraft flight level were provided by the Multiwavelength Aerosol Scatterometer (MAS) (Adriani et al., 1999), a backscattersonde that provided in-situ measurements of volume backscatter ratio and depolarization ratio at $532 \mathrm{~nm}$, with a time resolution of $10 \mathrm{~s}$ and an accuracy of 5\% on the backscatter ratio. The 2-sigma uncertainty on the depolarization ratio is higher and is estimated to be not smaller than $30 \%$ for the flight of 9 March to Davina.

The miniaturized lidar Microjoule Aerosol Lidar (MAL) (Matthey et al., 2000) provided vertical profiles of aerosol and cloud volume backscatter ratio and depolarization ratio at $532 \mathrm{~nm}$, from some tens of meters from the aircraft to 2$3 \mathrm{~km}$ upward, with a vertical resolution of $20 \mathrm{~m}$ and a time resolution of $80 \mathrm{~s}$.

Total water content was measured by the Fast In situ Stratospheric Hygrometer (FISH), developed at the Forschungszentrum Julich (Germany). The instrument that is based on the Lyman- $\alpha$ photofragment technique, has an overall accuracy of $6 \%$, or 0.3 ppmv in the case of very low mixing ratios. The oversampling of condensed water in clouds was corrected as described in Schiller et al. (1999). Condensed water was also measured by a Tunable Diode Laser (CVI) cell (Toci et al., 2002) that received only evaporated particles that had been able to pass a Counterflow Virtual Impactor (CVI) inlet (Noone et al., 1988). This latter device permitted the passage only of particles with kinetic energy larger than a given value, i.e. with masses equivalent to spherical diameters greater that $1.5 \mu \mathrm{m}$. Water vapour was measured by the FLASH instrument, an aircraft version of an instrument already deployed on balloons (Yushkov et al., 1998; Peet et al. 2004). While outside of clouds the two instruments give the same result, comparison of the two instruments in clouds gives the amount of condensed water. Ozone was measured with a time resolution of $10 \mathrm{~s}$ by the Electro Chemical Ozone Cell (ECOC) (Kyro et al., 2000), a modified electrochemical ozone cell whose data were validated against ozonosondes, and with a time resolution of $1 \mathrm{~s}$ by the Fast Ozone ANalyser (FOZAN) (Yushkov et al., 
1999), a fast response instrument based on a chemiluminescent reaction between a dye and the ambient ozone.

A set of long-lived tracers $\left(\mathrm{N}_{2} \mathrm{O}, \mathrm{CFC}-12\right.$, CFC-11, Halon$1211, \mathrm{SF}_{6}, \mathrm{CO}_{2}$ ) were measured by the High Altitude Gas AnalyzeR (HAGAR), a Gas chromatograph, with time resolution of $90 \mathrm{~s}$ combined with a non-dispersive IR analyzer for $\mathrm{CO}_{2}$ with time resolution of $10 \mathrm{~s}$ (Volk et al., 2000).

Avionic data were also recorded for scientific use. These included air temperature and pressure, horizontal wind velocity, true air speed, geographical coordinates and altitude. Accuracies of temperature and pressure were specified to be $0.5 \mathrm{~K}$ in temperature and $0.6 \mathrm{hPa}$ in pressure (B. Lepouchov, Myasishchev Design Bureau, Moscow Region, Russia, personal communication). Comparison with independent probes (Rosemount probes, colocated radiosoundings and a microwave temperature profiler) in previous and subsequent campaigns has confirmed this accuracy (Lowe et al., 2006). In principle, from the information of the inertial navigation system on aircraft orientation and true air speed, it would be possible to infer the values of air vertical speed which is an order of magnitude smaller than the horizontal components (Scott et al., 1990), but this was, in practice, not possible due to the noise affecting these avionic data.

\subsection{Satellites}

Images from METEOSAT 5 and TRMM were used for the analysis. TRMM data have also been used to evaluate the relevance of tropical storms for the global climate, as discussed in Sect. 2.

In the time frame of the Geophysica deployment, METEOSAT 5 was relocated over the Indian ocean at $63^{\circ} \mathrm{E}$ to provide support to the field activities of the concomitant international INDOEX project (Ramanathan et al., 2001). The satellite radiometer acquires images simultaneously in the visible, thermal infrared and water vapour IR band, with a frequency of $30 \mathrm{~min}$, a total coverage of the Earth disk and a spatial resolution of $5 \mathrm{~km}$ at the equator.

TRMM is a joint mission between NASA and JAXA, aiming to accurately measure the spatial and temporal variation of tropical rainfall. The instruments used to measure precipitation are two: i) the Precipitation Radar, (PR) that provides three-dimensional maps of storm structures with a horizontal resolution at the ground of $4 \mathrm{~km}$ and a swath width of $220 \mathrm{~km}$, and has the ability to provide vertical profiles of rain and snow from the surface up to a height of $20 \mathrm{~km}$, ii) the TRMM Microwave Imager (TMI), a passive microwave sensor based on the design of SSM/I which measures radiation at five separate frequencies with a $780 \mathrm{~km}$ wide swath at the ground.

\section{Observations}

\subsection{The Davina cyclone}

Davina originated on 1 March 1999 in the Mid-Indian Ocean basin, approximately due south of Sri Lanka. It maintained a west-south-west track almost throughout its life, reaching a tropical cyclone grade, as classified by the La Reunion Regional Specialized Meteorological Centre, on 5 March. Its maximum 10-min average wind speed was $162 \mathrm{~km} / \mathrm{h}$, detected on 7 and 8 March. After passing La Reunion island, it started to weaken and to decelerate, moving then northward and westward for several days. It dissipated over the waters of eastern Madagascar on 12 March.

Dvorak technique estimations (Dvorak, 1975, 1977, 1984) of tropical cyclone intensities suggest that the most intense stage of the storm had been reached on 8 March. The Geophysica sampled the cyclone early the following day, at the very beginning of its decaying phase. The onset of decay rapidly led to the disaggregation of the cyclone eye. TRMM data obtained from the DAAC database (in particular the VIRS radiance, the TMI radiances, and the TMI derived hydrometeor profiles), indicate that on 9 March 1999 part of such disaggregation had already started. The TMI hydrometeor data showed that the most active part of the storm was located near its southern edge. There, the surface rain due to convection was as high as $30 / 40 \mathrm{~mm} / \mathrm{h}$. Unfortunately the PR swath was located too far south to measure the height of the convective towers near the core of the system.

\subsection{The Geophysica flight}

The Geophysica took off from Mahé (Seychelles) the 9th of March 1999, at 05:05 local time (Seychelles time is $4 \mathrm{~h}$ ahead of UTC), following the DLR F-20 Falcon that took off $30 \mathrm{~min}$ earlier to act as a pathfinder. The Geophysica flight lasted for $5 \mathrm{~h}$ and $54 \mathrm{~s}$. In Fig. 1, a Meteosat image of brightness temperature over the Indian Ocean at the time of the Geophysica flight is shown. Segments of the Geophysica flight path of interest for this work, as explained in the following, are also displayed in the figure. Seven-day back-trajectories with ending points along the Geophysica flight path, calculated using NCEP reanalysis, showed the presence of a zonal easterly flow in the upper troposphere, in the week preceding the flight.

The two aircraft flew close together at their respective cruise altitudes. On approaching the centre of the cyclone, the OLEX lidar (on board of the Falcon) detected, above flight level, a thick cloud deck. The deck extended radially outward from the cyclone's eye for $400 \mathrm{~km}$, with clouds at $16 \mathrm{~km}$ in the outer boundaries, then sloping downward toward the cyclone's centre, to reach a cloud height of $8 \mathrm{~km}$ there. The weather radar on board of the Falcon detected a break in the eye wall and by following this passage the aircraft was able to reach the eye of Davina. The Geophysica 


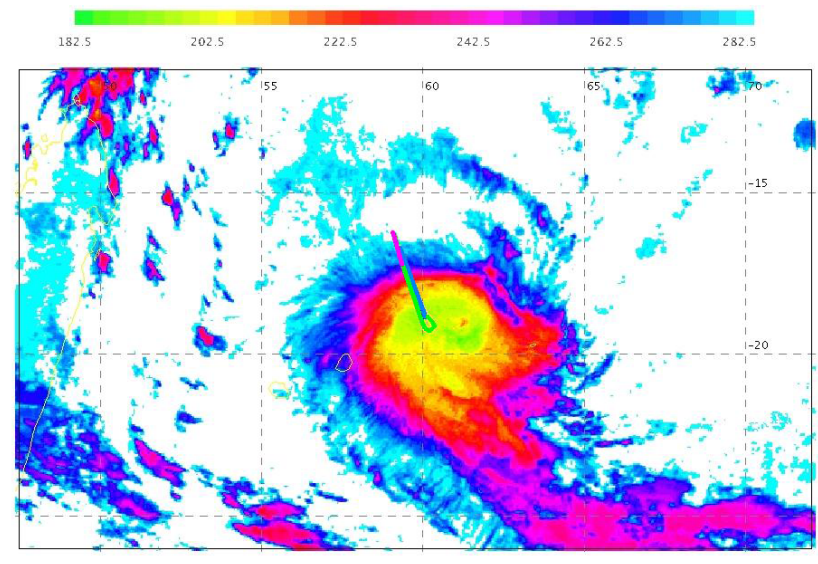

Fig. 1. Infrared brightness temperature $(\mathrm{K})$ observed by meteosat at 02:00 UTC in the area around cyclone Davina at the time of the Geophysica overpassing over the cyclone's eye. The segments coloured in blue, green and purple represents respectively portions $\mathrm{A} \mathrm{B}$ and $\mathrm{C}$ of the Geophysica flight as defined later on in the text and in Fig. 2. The eye of the cyclone can be identified in the area east and north of the deepest convection. A small displacement between the position of the eye and the track of the aeroplane is due to the fact only half hourly images from the satellite were available during the campaign.

followed the Falcon above the clouds and entered the cyclone in different areas, directly sampling the cirrus clouds and trace gases. During the cyclone crossing, the cirrus cloud deck that formed a spiral arm of Davina guided the Geophysica, and then a dive was performed at the cyclone wall. Figure 2 is a time plot of the flight altitude profile, (black line), together with MAS backscatter ratio (black line) and MAS depolarization (red line) showing crossings of clouds along the flight path.

The aircraft performed an ascent on approaching the cyclone centre (section A), then dived and turned northward (section B). A third ascent reached the aircraft ceiling altitude on the way back to Mahé (section C).

The ascents and descents were performed with a vertical speed of $4 \mathrm{~ms}-1$, sampling a region with horizontal dimension of roughly $350 \mathrm{~km}$. Data acquired along these three vertical profiles will be compared in the following to average profiles acquired in all other flights performed during the campaign. Data acquired during the portion of the flight marked in red, southward of $13^{\circ} \mathrm{S}$, are not part of the dataset used in the subsequent section to build mean profiles of temperature, ozone and tracers.

\subsection{Vertical profiles}

Data obtained during portions A, B, and C of the flight are compared with averages obtained from the campaign dataset composed of all the other flights, and the Davina flight data northward $13^{\circ} \mathrm{S}$. The dataset covers a wide variety of atmospheric conditions (see Stefanutti et al., 2004).

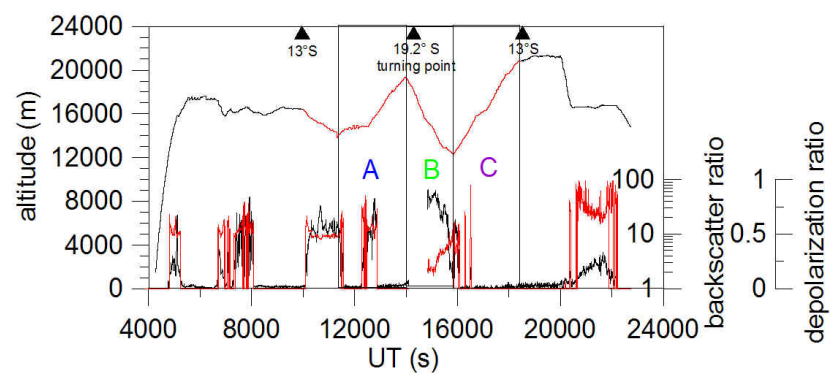

Fig. 2. Time series of the altitude profile of the Geophysica flight (black line, vertical axis on the left) and backscatter and aerosol depolarization ratio from the backscattersonde (black and red lines respectively, vertical axis on the right). Triangles denote geographical locations of interest. The three portions of the flight, indicated here as $\mathrm{A}, \mathrm{B}$, and $\mathrm{C}$ sections, are used to derive atmospheric vertical profiles in the following figures.

Most of this campaign dataset comes from observations northward of $13^{\circ} \mathrm{S}$, i.e. from a region well inside the socalled "tropical pipe" (Plumb, 1996), which is characterised by substantial isolation from the extra tropical lower stratosphere (Volk et al., 1996). The outermost edges of the tropical belt, though, may exhibit more meridional exchange with the midlatitudes or even lie outside the isolated tropical pipe region. In order to take full account of this possible bias in the average profiles, we also display in the figures, as a separate profile, the subset of the campaign observations composed of data acquired southward of $-13^{\circ} \mathrm{N}$ (excluding the Davina flight). These came from the flights, conducted on the 6 and 11 March, under convectively quiescent conditions and aimed at performing meridional transects of the tropopause region and the lower stratosphere to study tracer gradients.

Data from instruments with time resolution coarser than $1 \mathrm{~s}$ have been linearly interpolated to a 1-s grid, with the exception of HAGAR data for which the original data (sampled every $90 \mathrm{~s}$ ) are shown. The dataset has been binned in 60-m bins with respect to GPS altitude, with an average number of samples per bin of 300 , or in $1 \mathrm{~K}$ bins with respect to potential temperature, with an average number of samples per bin of roughly 500 (except for HAGAR data).

Figure 3 shows temperature (left panel) and potential temperature (right panel) profiles for the non-Davina campaign mean, the non-Davina campaign subset of observations southward of $13^{\circ} \mathrm{S}$ and for the three profiles from Davina. There, and in the following Figs. 4 to 10, the red solid line shows the non-Davina campaign profiles and the range bars indicate one standard deviation. Blue, green and purple solid lines show profiles acquired respectively during portions $\mathrm{A}$, $\mathrm{B}$ and $\mathrm{C}$ of the Davina flight, as indicated in Fig. 2. Finally the gray and black solid lines shows the non-Davina southernmost subset, respectively before and after the cyclone's passage.

From Fig. 3 we see that temperature profiles in and around the storm are up to $5 \mathrm{~K}$ warmer than the non-Davina mean in 


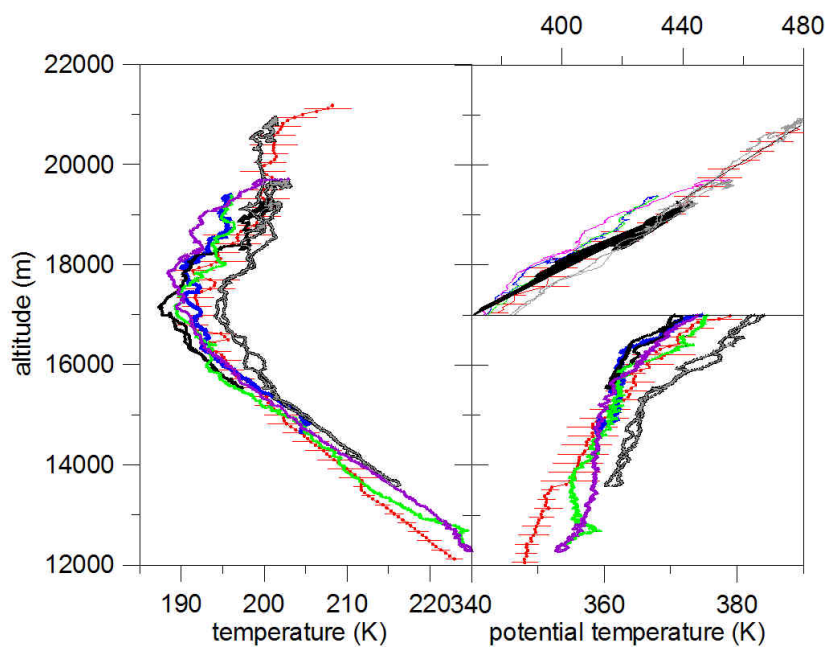

Fig. 3. Temperature (left panel) and potential temperature (right panel) vs geometrical altitude. Potential temperature data are displayed with respect to two different horizontal axes for ease of interpretation. Solid red lines represent the average non-Davina profiles observed during the campaign, range bars show \pm 1 standard deviation. Gray and black lines are the profile form a subsample of the campaign dataset with observations southward of $13^{\circ} \mathrm{S}$, (not comprising the Davina flight) taken respectively before and after the Davina passing. Blue, green and purple profiles denotes the profiles obtained respectively on portions A, B and C during the Davina flight, as displayed in Fig. 2.

the lower part of the profile between $12 \mathrm{~km}$ and $14 \mathrm{~km}$, then from $14 \mathrm{~km}$ up to $17 \mathrm{~km}$ they follow the non-Davina mean, while higher up they get some $3-5 \mathrm{~K}$ colder than the mean, up to $20 \mathrm{~km}$.

The non-Davina southernmost subset comprises two vertical profiles sampled on the 6 March between $17^{\circ}$ to $19^{\circ} \mathrm{S}$ (grey line), and one sampled on the 11 March between $13.5^{\circ}$ and $15^{\circ} \mathrm{S}$ (black line). Observations from these profiles are often at the two extremes of the overall campaign distribution for most quantities measured. Concerning temperature, we see that from $15-16 \mathrm{~km}$ to the top of the sounding, Davina profiles are $5-10 \mathrm{~K}$ colder than the non-Davina southernmost profiles acquired three days earlier, and are comparable to the profile acquired two days later, up to $18 \mathrm{~km}$. Above that altitude, the Davina profile stays colder than all other observations.

The cold point tropopause above the cyclone tends to be colder than the mean, although still within the envelope of cold points observed at other times during the campaign.

Potential temperature profiles around the centre of the hurricane are warmer than non-Davina means at altitudes below $13 \mathrm{~km}$, then in a layer from $13 \mathrm{~km}$ to $16 \mathrm{~km}$ the potential temperature vertical gradients are reduced so that above $16 \mathrm{~km}$, up to $19 \mathrm{~km}$, the Davina profiles become some 5-10 K colder than the non-Davina means. The comparison with the non-Davina southernmost subset shows Davina profiles be-

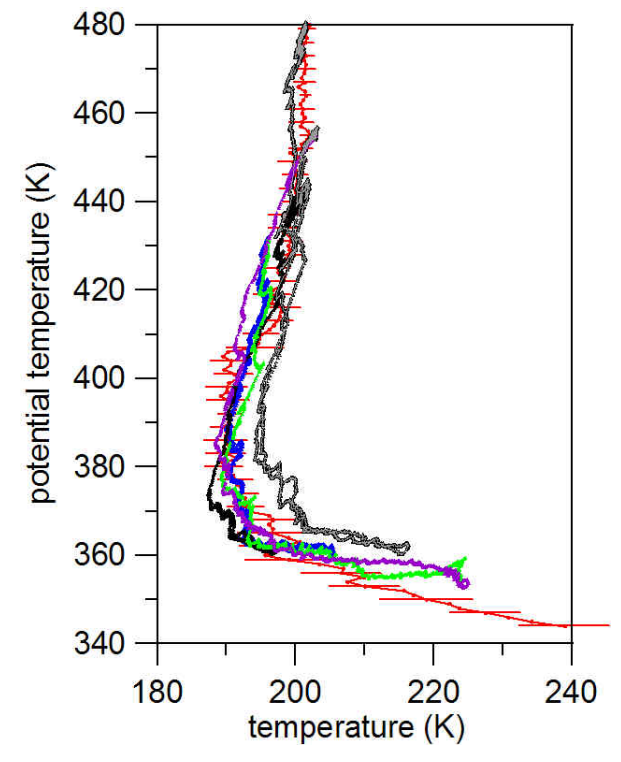

Fig. 4. Temperature vs. potential temperature. Solid red lines represent the average non-Davina profiles observed during the campaign, range bars show \pm 1 standard deviation. Gray and black lines are the profile form a subsample of the campaign dataset with observations southward of $13^{\circ} \mathrm{S}$, (not comprising the Davina flight) taken respectively before and after the Davina passing. Blue, green and purple profiles denotes the profiles obtained respectively on portions A, B and $\mathrm{C}$ during the Davina flight.

ing comparable to the profile sampled on 11 March, but some $5-10 \mathrm{~K}$ colder than the southernmost profiles sampled on 6 March in the upper troposphere, and in the lower part of the stratosphere. At the top of the sounding, these profiles merge with the non-Davina means.

In Fig. 4 we plot temperature profiles vs. potential temperature. From the $360 \mathrm{~K}$ level upwards, between 15 and $16 \mathrm{~km}$, the Davina profiles follow quite closely the nonDavina mean, suggesting that the temperature anomalies discussed in Fig. 3 are mainly due to adiabatic vertical displacement. Only below $360 \mathrm{~K}$, significant departures of the Davina profiles from the non-Davina mean suggest that diabatic processes become important. Hereafter we will generally use potential temperature as a vertical coordinate, to remove the effects of adiabatic motion.

The southernmost non-Davina profiles acquired on the 6 March are warmer than the overall non-Davina campaign mean until $420 \mathrm{~K}$, and warmer than the Davina case throughout the potential temperature range of the Davina profiles (i.e. $\theta \leq 450 \mathrm{~K}$ ), while the southernmost non-Davina profile acquired on the 11 March follow more closely the Davina profiles.

Water profiles are depicted in Fig. 5. As in previous pictures, red lines and range bars show the mean non-Davina total water campaign profile with a range of one standard deviation. Blue, green and purple solid lines show profiles 


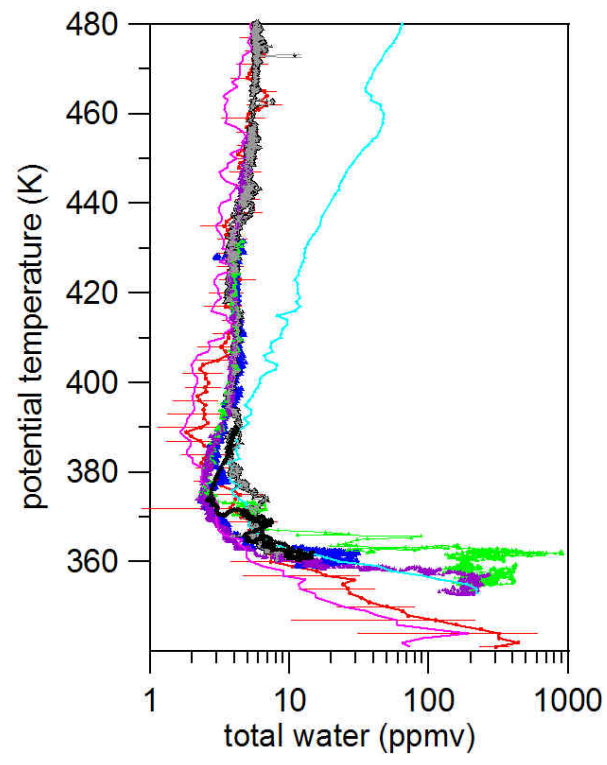

Fig. 5. Total water vs. potential temperature. Solid red lines represent the average non-Davina profiles observed during the campaign, range bars show \pm 1 standard deviation. Gray and black lines are the profile form a subsample of the campaign dataset with observations southward of $13^{\circ} \mathrm{S}$, (not comprising the Davina flight) taken respectively before and after the Davina passing. Blue, green and purple profiles denotes the profiles obtained respectively on portions A, B and $C$ during the Davina flight. In addition to total water data, the cyan solid line represent the water vapour saturation mixing ratio computed from air temperature during the Davina flight, the violet solid line represent the non-Davina mean water vapour mixing ratio, from the FLASH intrument.

acquired respectively during portions $\mathrm{A}, \mathrm{B}$ and $\mathrm{C}$ of the Davina flight, from FISH. In addition, the cyan solid line represents the water vapour saturation mixing ratio computed from the air temperature during the Davina flight and the violet solid line represents the non-Davina mean water vapour mixing ratio from FLASH.

The Davina profiles show a noticeable enhancement of the total water content in the TTL region up to $360 \mathrm{~K}$, i.e. up to the top of the cirrus deck. This is particularly marked on the $B$ profile where the cirrus layer extends even higher than in the other two profiles, up to $375 \mathrm{~K}$. We note, however, above $360 \mathrm{~K}$ in profiles $\mathrm{A}$ and $\mathrm{C}$ and above $375 \mathrm{~K}$ in profile $\mathrm{B}$, a distinct water depleted region. That region is substantially subsaturated, except for a single layer on profile A at $380 \mathrm{~K}$, where the water vapour reaches its saturation value.

In general, the Davina profiles differ significantly from the non-Davina means: mixing ratios at the hygropause are comparable but the Davina hygropause is some $20 \mathrm{~K}$ lower than for the non-Davina mean. The Davina profiles are dryer up to $385 \mathrm{~K}$, and moister above, merging with the non-Davina means only above the $410 \mathrm{~K}$ level.

Figure 6 shows the ozone measurements, which are of particular interest: in the Davina ozone profiles, the $360 \mathrm{~K}$ level

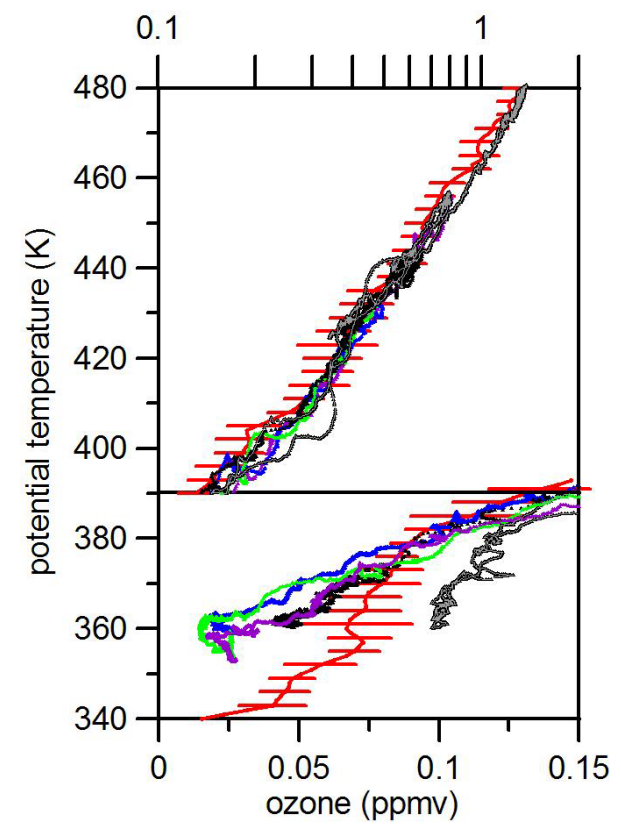

Fig. 6. Ozone vs. potential temperature. Solid red lines represent the average non-Davina profiles observed during the campaign, range bars show \pm 1 standard deviation. Gray and black lines are the profile form a subsample of the campaign dataset with observations southward of $13^{\circ} \mathrm{S}$, (not comprising the Davina flight) taken respectively before and after the Davina passing. Blue, green and purple profiles denotes the profiles obtained respectively on portions A, B and $\mathrm{C}$ during the Davina flight.

coincides with the centre of a layer, extending upward to the $380 \mathrm{~K}$ level, where ozone is strongly reduced, both in comparison with the non-Davina means and with the southernmost non-Davina profiles on 6 March, while the southernmost profile acquired on the 11 shows a reduction of ozone too, although not as severe as in the Davina observations. The depleted ozone in the Davina case is indicative of significant upward transport of ozone-poor marine boundary layer air into the TTL. The mean value of ozone mixing ratio below $850 \mathrm{hPa}$ during the campaign was around $20 \mathrm{ppbv}$, roughly half of the free troposphere value. Above the $380 \mathrm{~K}$ level, the Davina profiles are well within the non-Davina means.

Profiles of the tropospheric tracers $\mathrm{N}_{2} \mathrm{O}$ and CFC- 12 can be seen in Fig. 7. For both species the profiles A and B show a departure from the non-Davina means from the $400 \mathrm{~K}$ level upward, while profile $\mathrm{C}$ more closely follows the campaign means. Other long-lived tracers measured by HAGAR show similar behaviour. Noteworthy is furthermore the deviation from the non-Davina means at $440 \mathrm{~K}$, apparent in the southernmost profile acquired on the 11 March.

From the observations described above we can draw the following conclusions:

1. The cyclone induced a variation in the temperature profile of the UTLS, with temperatures that are warmer 


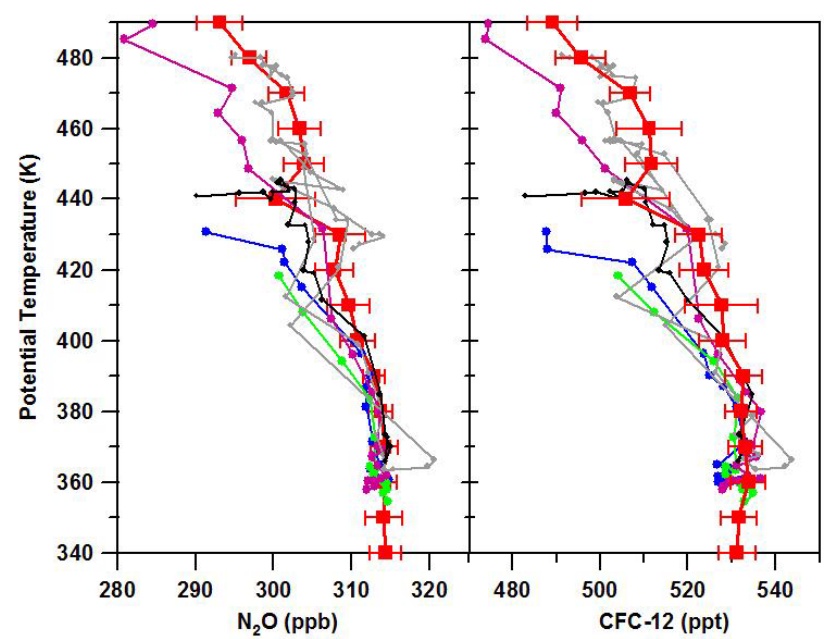

Fig. 7. Mixing ratios of $\mathrm{N}_{2} \mathrm{O}$ (left panel) and CFC-12 (right panel) measured by HAGAR vs potential temperature. Red squares represent the averages of non-Davina profiles (in $10 \mathrm{~K}$ bins of potential temperature) observed during the campaign, with range bars showing \pm 1 standard deviation. Gray and black lines are the profile form a subsample of the campaign dataset with observations southward of $13^{\circ} \mathrm{S}$, (not comprising the Davina flight) taken respectively before and after the Davina passing. Blue, green and purple circles connected by lines denote the profiles obtained respectively on portions $\mathrm{A}, \mathrm{B}$ and $\mathrm{C}$ during the Davina flight.

than average in the lower part of the TTL and colder than average in the upper TTL; stratospheric temperatures are generally colder than average, up to $20 \mathrm{~km}$ $(440 \mathrm{~K})$, which is the highest point reached by the aircraft near Davina.

2. In the tropopause region the vertical gradient of potential temperature is reduced.

3. Ozone is reduced from at least $360 \mathrm{~K}$ (probably lower) up to $380 \mathrm{~K}$, which suggests a vigorous uplift of ozone-poor marine-boundary-layer air to those altitudes, ((i.e. $\sim 17 \mathrm{~km})$. The reduction of ozone at $360 \mathrm{~K}$ is a factor of $\sim 4$ when compared with the non-Davina means, and attain there a value typical of the maritime PBL measured during the campaign.

4. There is a significant presence of cirrus clouds in the lower TTL above the cyclone, in one case extending upward to the cold point. The clouds reside in a region which is, as stated, colder than the mean. Where clouds are present, total water profiles are moister than the non-Davina means, implying that the cirrus clouds are forming in air injected into the TTL from below.

5. Tracer profiles stay within tropospheric values up to $385 \mathrm{~K}$. Above that level they show a stratospheric behaviour.

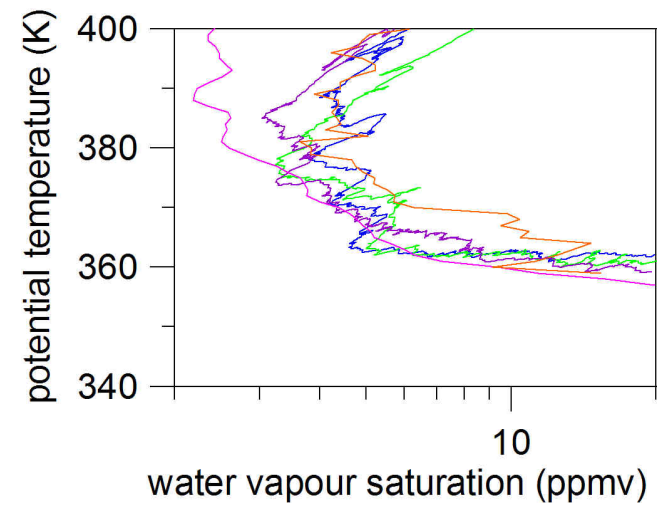

Fig. 8. Orange line is the non-Davina mean profile of water vapour saturation mixing ratio from the geophysica temperature measurement during the campaign. Pink line is the non-Davina mean of the water vapour mixing ratio observed during the campaign. The blue, green and purple are the saturation mixing ratio observed over Davina, along the A, B and $\mathrm{C}$ profiles respectively.

6. Where no clouds are present, water profiles are dryer below and moister above the $385 \mathrm{~K}$ level in comparison to the non-Davina means.

7. In general, Davina observations are closer to observations taken in the same area two days later, than to the overall campaign means and to the southernmost observations acquired three days earlier. This suggests that some of the effects of Davina were still persistent in the area after the storm had passed.

\section{Discussion}

From the previous analysis of ozone and tropospheric tracers, we are led to the conclusion that, despite the reduction of the vertical gradient of potential temperature, that would lead to a more permeable TTL, no stratospheric intrusions into the upper troposphere were observed during our survey, as could be assessed by the constant values of $\mathrm{N}_{2} \mathrm{O}$ and CFC- 12 and the absence of layers of enhanced ozone or reduced $\mathrm{H}_{2} \mathrm{O}$ to stratospheric values in the troposphere, and that the 380 $385 \mathrm{~K}$ level marked the upper boundary of a region subject to injections of boundary layer air during an earlier, more intense, phase of the cyclone. We will continue our analysis by focusing on the regimes below and above this level in turn.

\subsection{Below $385 \mathrm{~K}$ : dehydration effects}

In analyzing this set of observations, we were also motivated by the following question: are tropical cyclones active sites of dehydration, and to what extent? A partial answer to this question is that, despite the general effect of hydrating the upper troposphere (Ray et al., 2007), in fact they may be effective in dehydrating the air in the upper TTL. This may 
occur if the thick cirrus shield is present in a region of temperatures colder than the average, so that sedimenting cirrus particles would fix the water vapour there at a value close to the saturation, which is lower than the average saturation mixing ratio of the TTL elsewhere.

That this may be the case is suggested by an analysis of Fig. 8. There, the orange line represents the non-Davina mean saturation mixing ratio while the pink line represents the non-Davina mean water vapour mixing ratio, in cloudfree airmasses. As can be seen comparing the two profiles, in general during the campaign the air in the TTL was predominantly under-saturated, as reported in the analysis of MacKenzie et al. (2006). The Davina A, B and C saturation mixing ratio profiles - blue, red and purple lines respectively - are lower than the corresponding non-Davina means, and closer to the actual mean water vapour mixing ratio observed during the campaign.

The observations thus suggest that the upper part of the TTL above the cyclone is a good candidate for a region where the water vapor mixing ratio could be lowered, by freeze drying, to the values observed on average elsewhere, by an active process of freeze drying to the particularly low saturation values encountered there. A plausible mechanism for the dehydration is the formation of cirrus clouds at high levels, and subsequent particle removal by gravitational settling. This would leave the TTL temporarily colder than the mean and with a water vapour mixing ratio reduced to the small values of saturation encountered at the cloud tops there.

To explore further the water behaviour above the cyclone, we refer now to each single profile separately in Fig. 9 where $\mathrm{N}_{2} \mathrm{O}$, ozone, total water, water vapour saturation mixing ratio and aerosol depolarization ratio are displayed vs. geometrical altitude for the three Davina vertical soundings. We remind that profiles $\mathrm{A}$ and $\mathrm{C}$ were acquired in the northern wall of the cyclone while profile $\mathrm{B}$ is closer to the centre.

Common to the three profiles is a dry region between $16.5 \mathrm{~km}$ and $18 \mathrm{~km}$. Two geometrically thin layers of condensed water are present lower down in profile $\mathrm{C}$, where total water is at, or only slightly above, the water vapour saturation mixing ratio. Profile B shows a thick cirrus up to $16 \mathrm{~km}$. Unfortunately the aerosol depolarization data are missing for the central part of this profile, so we cannot detect whether or not the condensed phase extends up to $16.5 \mathrm{~km}$, where the total water content equals the saturation value. Nevertheless, noticeable in the available dataset is the unexpectedly low value of the aerosol depolarization inside that cloud. Such low values are detected in mixed phase clouds, unlikely to be present at those cold temperatures, or in clouds composed of particles of very small radius, probably from very recent nucleation. Significant presence of small particles inside the cyclone cirrus canopy was reported by Knollenberg et al. (1993) in the case of cyclone Damien.

In the case of high densities of small cloud particles, equilibrium with the water vapour inside the cloud could be established very quickly, thus reducing the amount of water in

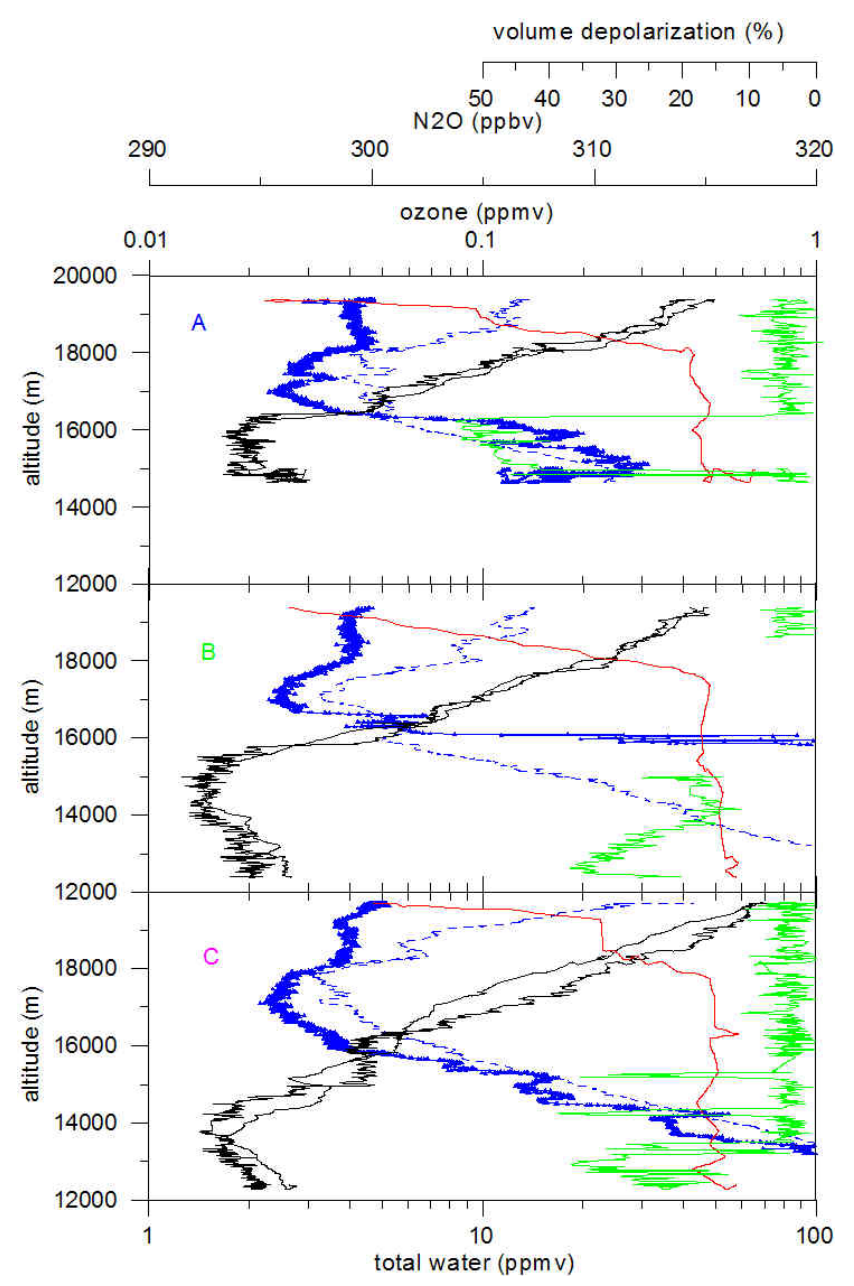

Fig. 9. Solid blue lines show the total wapor mixing ration from FISH. Dashed blue lines show the water vapor saturation mixing ratio from temperature measurements. Black lines are ozone mixing ratios from FOZAN (the more structured one) and ECOC (the smoother one). Red lines are $\mathrm{N}_{2} \mathrm{O}$ mixing ratio from HAGAR. Green lines shows depolarization ratio from MAS. Data from MAS are missing for part of the flight. Upper, middle and lower panel are for profiles A, B and C respectively, as depicted in Fig. 2.

the gas phase to a value close to its saturation in short times. Yet, the minimum of water vapour found at $17 \mathrm{~km}$ in all the three profiles would have required temperatures $2-3 \mathrm{~K}$ lower than those actually encountered at the cirrus cloud tops in our sounding.

In fact hygropause and cold point (see the minimum in the total water mixing ratio profile) are coincident only in the B case, while both in the A and C profiles they differ, the cold point being higher than the hygropause. In case $\mathrm{B}$, the cold point coincides with the altitude of the computed lapse rate tropopause, while the cold point is higher than the lapse rate tropopause in cases A and C. This all seems to suggest that dehydration processes are thus not ongoing in our data, except maybe at the top of the cirrus clouds in profile $\mathrm{B}$, and 


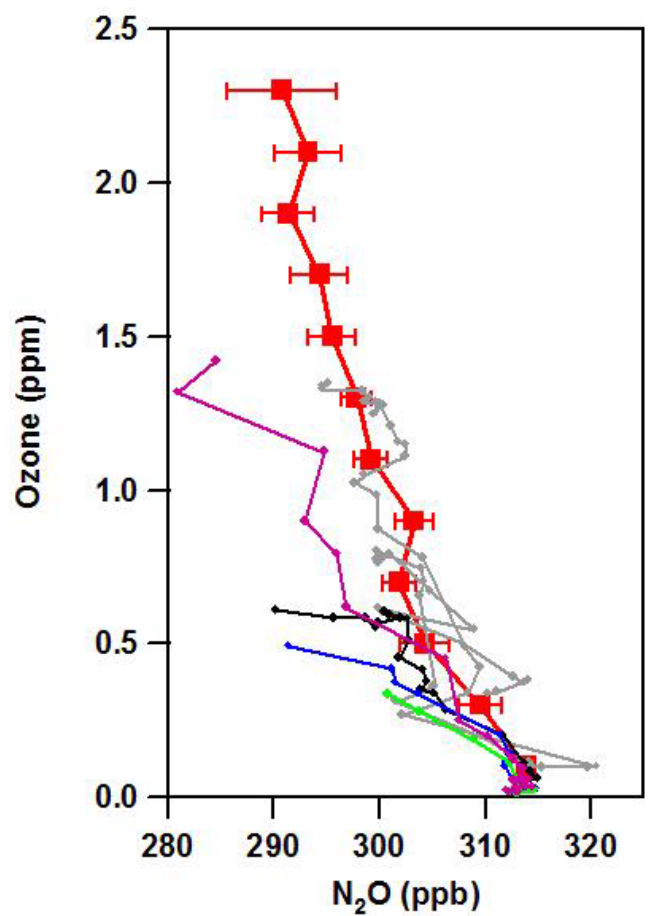

Fig. 10. Scatterplot of ozone vs $\mathrm{N}_{2} \mathrm{O}$. Solid red line represent the averages of non-Davina profiles (in bins of $0.1 \mathrm{ppm}$ ozone) observed during the campaign, with range bars showing \pm 1 standard deviation. Gray and black lines are the profile form a subsample of the campaign dataset with observations southward of $13^{\circ} \mathrm{S}$, (not comprising the Davina flight) taken respectively before and after the Davina passing. Blue, green and purple lines denote the profiles obtained respectively on portions A, B and C during the Davina flight.

that the dry layer between $16 \mathrm{~km}$ and $18 \mathrm{~km}$ is a result of what had happened earlier, perhaps in the most active part of the cyclone life cycle. During intensification, the cyclone experienced a large drop in its central surface pressure and it is then that the most intense vertical velocities are usually observed. This hypothesis was substantiated by the analysis of the available TRMM data that measured the cyclone during different stages of its life cycle, and showed how colder cloud tops were observed $48-72 \mathrm{~h}$ earlier than our observations.

An effect probably competing with dehydration may arise from overshooting cloud turrets hydrating that region, as seemed to be the case in profile $\mathrm{A}$, where a temperature minimum at $17.5 \mathrm{~km}$ is just coincident with a thin layer of enhanced water vapour, reaching its saturation value. Particles in that layer were identified by the slight enhancement observed in the MAS depolarization (green line) and in concomitant enhancement of the CVI condensed water probe (not shown). Such moisturizing anvil top plumes originating from the cirrus decks above thunderstorms have been first described from satellite observations by Levizzani et al. (1996). Wang (2003) interpreted these as injections of small particles in the upper levels induced by the breaking of gravity waves;

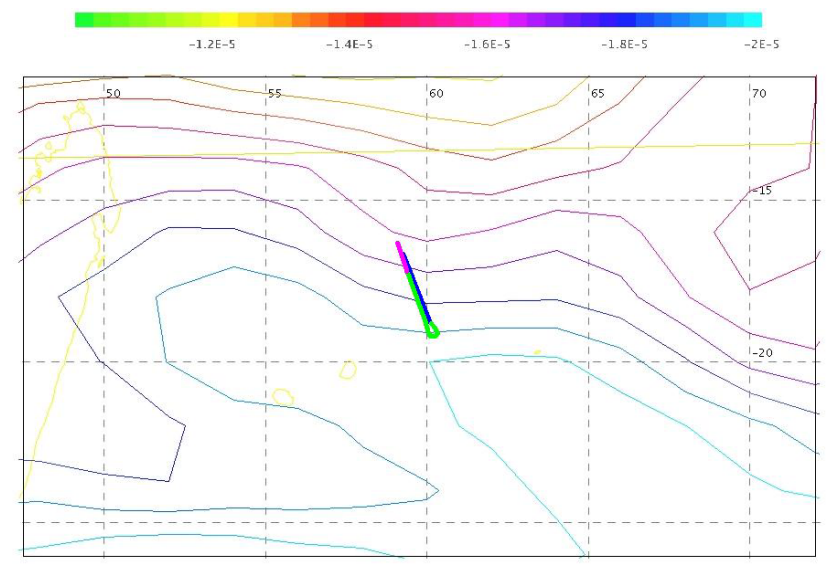

Fig. 11. Potential vorticity on the $430 \mathrm{~K}$ theta surface for 9 March 1999 as obtained from ERA40 reanalysis. Davina lies in a region of high gradient where isolated filaments can mix air of extra tropical latitudes in the tropical pipe. One of these elongated structure can be seen extending from east to west over the area interested by the cyclone.

the small particles then moisturize the layer upon evaporation. Turbulent mixing induced by breaking gravity waves may be enhanced in the weakly stratified tropopause region above cyclones. Turbulent mixing above ITCZ-type convection leading - on subsequent cooling - to cloud formation, has been described by Santacesaria et al. (2003) for an earlier flight in APE-THESEO, and by Garrett et al. (2004) for measurements in the CRYSTAL-FACE campaign. 5.2 Above $385 \mathrm{~K}$ : meridional mixing in the lower strato-
sphere

As shown in Fig. 7, stratospheric tracers showed a distinctive behaviour in the vicinity of cyclone Davina between $400 \mathrm{~K}$ and $430 \mathrm{~K}$. There, on two out of three profiles the vertical profiles of $\mathrm{N}_{2} \mathrm{O}$ and CFCs show lower mixing ratios tending toward values that are typical of the midlatitude stratosphere than of tropical air. The scatterplot of $\mathrm{N}_{2} \mathrm{O}$ vs. ozone in Fig. 10 further confirms this feature: while the non-Davina campaign data on average exhibit a correlation slope typical for the isolated tropical regions, the deviations apparent in the Davina profiles tend toward the compact correlation typically observed in the midlatitudes (e.g. Volk et al., 1996). This suggests that stratospheric air above the cyclone is at least partly of midlatitude origin.

Indeed, HYSPLIT (Draxler and Rolph, 2003; Rolph, 2003) model backtrajectories starting on a $1^{\circ}$ square grid centered at the southernmost point of the Geophysica flight path confirm that, above the cyclone eye and higher than $400 \mathrm{~K}$, air-masses follow two tracks: a purely zonal trak staying well within the tropics and a more meridional track, which is apparent eastward of Madagascar, displacing midlatitude air-masses toward the tropics. This latter flux 
promoted a $15^{\circ}$ northward displacement of the air-masses in the previous $72 \mathrm{~h}$. If this meridional transport has indeed occurred, it could well account for the observations taken by the Geophysica in the stratosphere above the cyclone.

Figure 11 shows a contour plot of Potential Vorticity on the $430 \mathrm{~K}$ theta surface for 9 March 1999 as obtained from ERA40 reanalysis, superimposed to the Geophysica flight segment marked as A, B and C in our work. As can be seen, Davina lies below a stratospheric region of high PV gradient where isolated filaments can mix air of extra tropical latitudes in the tropical pipe. One of these elongated structure can be seen extending from east to west over the area interested by the cyclone. A prominent ridge, not shown, appeared higher up in the stratosphere.

It needs to be considered here that the observations in question were taken in just the region $\left(13^{\circ}\right.$ to $\left.19^{\circ} \mathrm{S}\right)$ in which the subtropical barrier is usually found (e.g. Fahey et al., 1996). Air of both typical tropical as well as more midlatitude character may thus be expected in this region, depending on the exact location of the barrier, which is expected to undulate meridionally e.g. under the influence of large-scale waves and which may possess small-scale structure. This would explain the fact that the non-Davina profiles southward of $13^{\circ} \mathrm{S}$ exhibit partially typically tropical tracer values (and correlation slope with ozone) and partially similar excursions toward midlatitude values as the Davina profiles (see Figs. 7 and 10). Whether the meridional transport associated with Davina constitutes an irreversible intrusion of midlatitude air into the tropical lower stratosphere or simply a large-scale northward displacement of the subtropical transport barrier, cannot be decided with the data set considered here. However, the cyclone would certainly be expected to interact with the subtropical transport barrier and it is quite conceivable that such interaction would promote irreversible exchange between the tropics and midlatitudes.

\section{Conclusions}

The encounter of the Geophysica research aircraft with cyclone Davina on 9 March 1999 provided in-situ measurements of trace gases, cloud/aerosol properties and thermodynamic properties in the tropopause layer and in the lower stratosphere. These measurements have been used to build a two dimensional picture of the atmosphere above a tropical cyclone. In particular, the measurements have been used to investigate the transport processes which could substantially modify the tropical tropopause layer.

In fact the low temperatures encountered in the upper part of the TTL may have triggered the formation of cirrus clouds at high levels, and subsequent particle removal by gravitational settling, thus leaving the TTL - temporarily colder than the mean - with a water vapour mixing ratio reduced to the small values of saturation encountered there.
The observations acquired during our survey showed a dehydrated layer in the upper part of the TTL above the cyclone cirrus canopy and displayed condensed water whenever its total abundance was above or matching the water vapour saturation value. Nevertheless these observations are neither conclusive in showing the dehydration mechanism in action, nor they can demonstrate its effectiveness in the past. Unfortunately, the cyclone was sampled at the onset of its decaying phase, when higher and colder clouds were likely already past. Although is tempting to attribute the observed low values of water vapour in the upper part of the TTL to dehydration processes that were active when colder temperatures and higher clouds were present, this can only be speculative.

The observations seem to suggest that cyclones may induce horizontal stirring of the lower stratosphere, possibly promoting irreversible entrainment of midlatitude stratospheric air into the tropical zone. They may thus act to smear out the "tape recorder" profile of water vapour vertically, and the meridional gradients of water and trace gases horizontally.

Acknowledgements. The APE-THESEO project was funded by the European Commission under the contract ENVSCY97-0533, by the Italian Space Agency (ASI), by the European Science Foundation and by the German Ministry of Science and Education (BMBF), all of whom gratefully acknowledged. Help in-kind was provided by the UK Meteorological Office and the Directorate of Civil Aviation of the Seychelles.

A. R. MacKenzie gratefully acknowledges NERC support under contracts GST/02/2210 and NER/T/S/00977.

This work also informs Activity 2 of the SCOUT-O3 Integrated Project of the European Commission (contract 505390-GOCE-CT2004) as part of that project's data mining and exploitation of existing data.

ECMWF ERA-40 data used in this study have been obtained from the ECMWF data server.

Edited by: P. Haynes

\section{References}

Adriani, A., Cairo, F., Viterbini, M., Mandolini, S., Pulvirenti, L., and Di Donfrancesco, G.: Multiwavelength Aerosol Scatterometer for airborne experiments to study the stratospheric particle optical properties, J. Atmos. Ocean. Tech., 16, 1329-1336, 1999.

Alcala, C. M. and Dessler, A. E.: Observation of deep convection in the tropics using the tropical Rainfall Mesurement Mission (TRMM) precipitation radar, J. Geophys. Res. 107, 1-7, 2002.

Atticks, M. G. and Robinson, G. D.: Some features of the structure of the tropical tropopause, Q. J. R. Meteorol. Soc., 109, 295-308, 1983.

Baray, J. L., Ancellet, G., Radriambelo, T., and Baldy, S.: Tropical cyclone Marlene and stratosphere-troposphere exchange, J. Geophys. Res., 104, 13 953-13 970, 1999.

Brewer, A. W.: Evidence for a world circulation provided by the measurement of helium and water vapour distribution in the stratosphere, Q. J. R. Meteorol. Soc., 75, 351-363, 1949. 
Buontempo, C., Flentje, H., and Kiemle, K.: In the eye of a tropical cyclone, Weather, 61, 47-50, 2006.

Carsey, T. P. and Willoughy, H. E: Ozone measurements from eyewall transects of two Atlantic tropical cyclones, Mon. Weather Rev., 133, 166-174, 2005.

Cecil, D. J., Goodman, S. J., Boccippio, D. J., Zipser, E. J., and Nesbitt, S. W.: Three years of TRMM Precipitation features: part I: Radar, Radiometric and lightning characteristics, Mon. Weather Rev. 133, 543-566, 2005.

Danielsen, E. F.: A dehydration mechanism for the stratosphere, Geophys. Res. Lett., 9, 605-608, 1982.

Danielsen, E. F.: In situ evidence of rapid, irreversible, vertical transport of lower tropospheric air int the lower tropical stratosphere by convective cloud turrets and by larger scale upwelling in tropical cyclones, J. Geophys. Res., 98(D5), 8665-8681, 1993.

Dessler, A. E.: The effect of deep, tropical convection on the tropical tropopause layer, J. Geophys. Res., 107(D), ACH 6-1, ACH 6-5, 2002.

Draxler, R. R. and Rolph, G. D.: HYSPLIT (HYbrid Single-Particle Lagrangian Integrated Trajectory) Model access via NOAA ARL READY Website (http://www.arl.noaa.gov/ready/hysplit4.html), NOAA Air Resources Laboratory, Silver Spring, MD, 2003.

Dvorak, V. F.: Tropical cyclone analysis and forecasting from satellite imagery, Mon. Weather Rev., 103, 420-430, 1975.

Dvorak, V. F.: Tropical cyclones intensity analysis using enhanced infrared satellite data, proceedings of the 11th technical conference on hurricanes and tropical meteoreology, AMS, 268-273, 1977.

Dvorak, V. F.: Tropical cyclone intensity analysis using satellite data, NOAA Technical Report NESDIS 11, NOAA/NESDIS, 47 pp., 1984.

Ebert, E. E. and Holland, G. J.: Observation of record cloud top temperature in tropical cyclone Hilda (1990), Mon. Weather Rev., 120, 2240-2251, 1991.

Elkins, J. W., Thompson, T. M., Swanson, T. H., Butler, J. H., Hall, B. D., Cummings, S. O., Fisher, D. A., and Raffo, A. G.: Decrease in the growth rates of atmospheric chlorofluorocarbons 11 and 12, Nature 364, 780-783, 1993.

Emanuel, K.: Thermodynamic control of cyclone intensity, Nature, 401, 665-669, 1999.

Emanuel, K.: Tropical Cyclones, Annu. Rev. Earth Planet. Sci., 31, 75-104, 2003.

Emanuel, K. A.: Increasing destructiveness of tropical cyclones over the past 30 years, Nature 326, 686-668, 2005.

Fahey, D. W., Donnelly, S. G., Keim, E. R., Gao, R. S., Wamsley, R. C., Del, L. A., Negro, E. L., Woodbridge, M. H., Proffitt, K. H., Rosenlof, M. K. W., Ko, D. K., Weisenstein, C. J., Scott, C., Nevison, S., Solomon, S., and Chan, K. R.: In situ observations of $\mathrm{NO}_{\mathrm{y}}, \mathrm{O}_{3}$, and the $\mathrm{NO}_{\mathrm{y}} / \mathrm{O}_{3}$ ratio in the lower stratosphere, Geophys. Res. Lett., 23, 1653-1656, 1996.

Folkins, I., Loewenstein, M., Podolske, J., Oltmans, S. J., and Profitt, M.: A barrier to vertical mixing at $14 \mathrm{~km}$ in the tropics: Evidences from ozonesondes and aircraft measurements, J. Geophys. Res., 104, 22 095-22 102, 1999.

Folkins, I., Oltmans, S. J., and Thompson, A. M.: Tropical convective outflow and near surface equivalent potential temperatures, Geophys. Res. Lett., 27, 2549-2552, 2000.

Folkins, I., Braun, C., Thompson, A. M., and Witte, J.: Tropical ozone as an indicator of deep convection, J. Geophys. Res.,
107(D13), 4184, doi:10.1029/2001JD001178, 2002.

Fueglistaler, S., Wernli, H., and Peter, T.: Tropical troposphere to stratosphere transport inferred from trajectory calculations, J. Geophys. Res., 109, D3108, doi:10.1029/2003JD004069, 2004.

Fujiwara, M., Kita, K., Ogawa, T., Kawakami, S., Sano, T., Komala, N., Saraspriya, S., and Suripto, A.: Seasonal variation of tropospheric ozone in Indonesia revealed by 5 -years ground based observations, J. Geophys. Res., 105, 1879-1888, 2000.

Garrett, T. J., Heymsfield, A. J., McGill M. J., Ridley, B. A., Baumgardner, D. G., Bui, T. P., and Webster, C. R.: Convective generation of cirrus near the tropopause, J. Geophys. Res., 109, D21203, doi:10.1029/2004JD004952, 2004.

Gettelman, A., Salby M. L. and Sassi F., The distribution and influence of convection in the tropical tropopause region, J. Geophys. Res, 107(D10), doi:10.1029/2001JD001048, 2002.

Highwood, E. J. and Hoskins, B. J.: The tropical tropopause, Q. J. R. Meteorol. Soc., 124, 1579-1604, 1998.

Holton, J. R., Haynes, P. H., McIntyre, M. E., Douglass, A. R., Rood, R. B., and Pfister, L.: Stratosphere troposphere exchange, Rev. Geophys., 33, 403-439, 1995.

Holton, J. R. and Gettelman, A.: Horizontal transport and the dehydration of the stratosphere, Geophys. Res. Lett., 28, 2799-2802, 2001.

Joiner, J., Vasilkov, A., Yang, K., and Bhartia, P. K: Observations over hurricanes from the ozone monitoring instrument, Geophys. Res. Lett., 33, L06807, doi:10.1029/2005GL025592, 2006.

Kelley, O. A. and Stout, J.: Convective towers in eyewalls of tropical cyclones observed by the TRMM precipitation radar in 19982001, Proceedings of the AMS 20th Conference on Weather Analysis and Forecast/16 Conference of Numerical Weather Prediction, 12-16 January 2004, Seattle, Washington.

Kirk-Davidoff, D. B., Anderson, J. G., Hintsa, E. J., and Keith, D. W.: The effect of climate change on ozone depletion through changes in stratospheric water vapour, Nature, 402, 399-401, 1999.

Knollemberg, R. G., Kelly, K., and Wilson, J. C.: Measurements of high number densities of Ice Crystals in the tops of tropical cumulonimbus, J. Geophys. Res., 98, 8639-8664, 1993.

Koteswaram, P.: On the structure of hurricanes in the upper troposphere and lower stratosphere, Mon. Weather Rev., 95, 541-564, 1967.

Kovacs, T. A. and McCormick, M. P.: Observations of Typhoon Melissa during the Lidar In-Space Technology Experiment (LITE), J. Appl. Met. 42, 1003-1013, 2003.

Kritz, M. A., Rosner, S. W., Kelly, K. K., Loewenstein, M., and Chan, K. R.: Radon measurements in the lower tropical stratosphere: evidence for rapid vertical transport and dehydration of tropospheric air, J. Geophys. Res., 98, 8725-8736, 1993.

Kyro, E., Kiwi, R., Turunen, T., Aulamo, H., Rudakov, V. V., Khattatov, V. V., MacKenzie, A. R., Chipperfield, M. P., Lee, A. M., Stefanutti, L., and Ravegnani, F.: Ozone measurementsa during the Airborne Polar Experiment: aircraft instrument validation, isentropic trends and hemispheric fields prior to the 1997 Arctic ozone depletion, J. Geophys. Res., 105, 14 599-14612, 2000.

Leclair De Bellevue, J., Baray, J. L., Baldy, S., Ancellet, G., Diab, R., and Ravetta, F.: Simulations of stratospheric to tropospheric transport during the tropical cyclone Marlene event, Atmos. Environ., 41(31), 6510-6526, 2007.

Leclair De Bellevue, J., Réchou, A., Baray, J. L., Ancellet, G., and 
Diab, R. D.: Signatures of stratosphere to troposphere transport near deep convective events in the southern subtropics, J. Geophys. Res., 111, D24107, doi:10.1029/2005JD006947, 2006.

Levizzani, V. and Setvak, M.: Multispectral high resolution satellite observations of plumes on top of convective storms, J. Atmos. Sci., 53, 361-369, 1996.

Lowe, D., MacKenzie, A. R., Schlager, H., Voigt, C., Dörnbrack, A., Mahoney, M. J., and Cairo, F.: Liquid particle composition and heterogeneous reactions in a mountain wave Polar Stratospheric Cloud, Atmos. Chem. Phys., 6, 3611-3623, 2006, http://www.atmos-chem-phys.net/6/3611/2006/.

MacKenzie, A. R., Schiller, C., Peter, T., Adriani, A., Beuermann, J., Bujok, O., Cairo, F., Corti, T., Di Donfrancesco, G., Gemsch, I., Kiemle, C., Kramer, M., Kroger, C., Merkulov, V., Oulanovsky, A., Ravegnani, F., Rohs, S., Rudakov, V., Salter, P., Santacesaria, V., Stefanutti, L., and Yushkov, V.: Tropopause and Hygropause variability over the equatorial Indian ocean during February and March 1999, J. Geophys. Res., 111, D18112, doi:10.1029/2005JD006639, 2006.

Matthey, R., Mitev, V., Mileti, G., Makarov, V., Turin, A., Morandi, M., and Santacesaria, V.: Miniature aerosol lidar for automated airborne application, Laser radar technology and applications V; Proceedings of the Conference, Orlando, USA, 26-28 April 2000, 44-53, 2000.

Merrill, R. T.: Characteristics of the Upper-tropospheric Environmental flow around Hurricanes, J. Atmos. Sci., 45, 1665-1677, 1988.

Newell, R. E., Hu, W., Wu, Z.-X., Zhu, Y., Akimoto, H., Anderson, B. E., Browell, E. V., Gregory, G. L., Sachse, G. W., Shipham, M. C., Bachmeier, A. S., Bandy, A. R., Thornton, D. C., Blake, D. R., Rowland, F. S., Bradshaw, J. D., Crawford, J. H., Davis, D. D., Sandholm, S. T., Brockett, W., DeGreef, L., Lewis, D., McCormick, D., Monitz, E., Collins, J. E., Heikes, B. G., Merrill, J. T., Kelly, K. K., Liu, S. C., Kondo, Y., Koike, M., Liu, C.-M., Sakamaki, F., Singh, H. B., Dibb, J. E., and Talbot, R. W.: Atmospheric sampling of Supertyphoon Mireille with NASA DC-8 aircraft on September 27, 1991, during PEM-West A, J. Geophys. Res., 101(D1), 1853-1872, 1996.

Noone, K. J., Ogren, J. A., Heinzenberger, J., Charson, R. J., and Covert, D. S.: Design and calibration of a counterflow virtual impactor for sampling atmospheric fog and cloud droplets, Aerosol Sci. Tech., 8, 235-244, 1988.

Peet, E., Rudakov, V., Yushkov, V., Redaelli, G., and MacKenzie, A. R.: Ozone and water vapour in the austral polar stratospheric vortex and sub-vortex, Ann. Geophys., 22, 4035-4041, 2004, http://www.ann-geophys.net/22/4035/2004/.

Penn, S.: Ozone and temperature structure in a Hurricane, J. Appl. Meteorol. 4, 212-216, 1965.

Penn, S.: Temperature and ozone variations near tropopause level over hurricane Isbell, October 1964, J. Appl. Meteorol., 5, 407410, 1966

Plumb, R. A.: A tropical pipe model of strotospheric transport, J. Geophys. Res., 101, 3957-3972, 1996.

Ramanathan, V., Crutzen, P. J., Lelieveld, J., Mitra, A. P., Althausen, D., Anderson, J., Andreae, M. O., Cantrell, W., Cass, G. R., Chung, C. E., Clarke, A. D., Coakley J. A., Collins, W. D., Conant, W. C., Dulac, F., Heintzenberg, J., Heymsfield, A. J., Holben, B., Howell, S., Hudson, J., Jayaraman, A., Kiehl, J. T., Krishnamurti, T. N., Lubin, D., McFarquhar, G., Novakov, T.,
Ogren, J. A., Podgorny, I. A., Prather, K., Priestley, K., Prospero, J. M., Quinn, P. K., Rajeev, K., Rasch, P., Rupert, S., Sadourny, R., Satheesh, S. K., Shaw, G. E., Sheridan P., and Valero, F. P. J.: Indian Ocean Experiment: an integrated analysis of the climate forcing and effects of the great indo-asian Haze, J. Geophys. Res., 106, 28 731-28 398, 2001.

Ray, E. A. and Rosenlof, K. H.: Hydration of the upper troposphere by tropical cyclones, J. Geophys. Res., 112, D12311, doi:10.1029/2006JD008009, 2007.

Richard, E. C., Rosenlof, K. H., Ray, E. A., Kelly, K. K., Thompson, T. L., and Mahoney, M. J.: Upper Tropospheric-Lower Stratospheric In-Situ Measurements Over Hurricane Floyd: The Impact of Tropical Cyclones on Stratosphere-Troposphere Exchange, EOS Trans., 82(47), Fall Meet. Suppl. Abstract A51H09, 2001.

Rolph, G. D: Real-time Environmental Applications and Display sYstem (READY) Website (http://www.arl.noaa.gov/ready/ hysplit4.html), NOAA Air Resources Laboratory, Silver Spring, MD, 2003.

Santacesaria, V., Carla, R., MacKenzie, A. R., Adriani, A., Cairo, F., Di Donfrancesco, G., Kiemle, C., Redaelli, G., Beuermann, J., Schiller, C., Peter, T., Luo, B., Wernli, H., Ravegnani, F., Ulanovsky, A., Yushkov, V., Sitnikov, N., Balestri, S., and Stefanutti, L.: Clouds at the tropical tropopause: A case study during the APE-THESEO campaign over the western Indian Ocean, J. Geophys. Res., 108(D2), 4044, doi:10.1029/2002JDJD002166, 2003.

Schiller, C., Afchine, A., Eicke, N., Feigl, C., Fischer, H., Giez, A., Konopka, P., Schlager, H., Tuitjer, F., Wienhold, F. G., and Zöger, M.: Ice particle formation and sedimentation in the tropopause region: a case study based on in-situ measurements of total water during POLSTAR 1997, Geophys. Res. Lett., 26, 2219-2222, 1999.

Scott, S. G., Bui, T. P., Chan, K. R., and Bowen, S. W.: The meteoreological measurement system on the NASA ER-2 aircraft, J. Atmos. Ocean. Tech., 7, 525-540, 1990.

Sherwood, S. C. and Dessler, A.: A model for transport across the tropical tropopause, J. Atmos. Sci., 58, 765-779, 2001.

Stefanutti, L., MacKenzie, A. R., Santacesaria, V., Adriani, A., Balestri, S., Borrmann, S., Khattatov, V., Mazzinghi, P., Mitev, V., Rudakov, V., Schiller, C., Toci, G., Volk, C. M., Yushkov, V., Flentje, H., Kiemle, C., Redaelli, G., Carslaw, K. S., Noone, K., and Peter, T.: The APE-THESEO tropical campaign: An overview, J. Atmos. Chem., 48, 1-33, 2004.

Teitelbaum, H., Moustaoui, M., Basdevant, C., and Holton, J. R.: An alternative mechanism explaining the hygropause formation in tropical regions, Geophys. Res. Lett., 27, 221-224, 2000.

Toci, G., Mazzinghi, P., Mielke, B., and Stefanutti, L.: An airborne diode laser spectrometer for the simultaneous measurement of $\mathrm{H}_{2} \mathrm{O}$ and $\mathrm{HNO}_{3}$ content of stratospheric cirrus clouds, Opt. Laser. Eng., 37, 459-480, 2002.

Vaughan, G., Shiller, C., Mackenzie, A. R., Bower, K., Peter, T., Schlager, H., Harris, N. R. P., and May, P. T.: SCOUTO3/ACTIVE: High altitude aircraft measurements around deep tropical convection, B. Am. Meterol. Soc., 89(5), 647-662, 2008.

Volk, C. M., Riediger, O., Strunk, M., Schmidt, U., Ravegnani, F., Ulanovsky, A., and Rudakov, V.: In situ Tracer Measurements in the Tropical Tropopause Region During APE-THESEO, Eur. Comm. Air Pollut. Res. Report 73, 661-664, 2000. 
Volk, C. M., Elkins, J. W., Fahey D. W., Salawitch, R. J., Dutton, G. S., Gilligan, J. M., Proffitt, M. H., Loewenstein, M., Podolske, J. R., Minschwaner, K., Margitan, J. J., and Chan, K. R.: Quantifying transport between the tropical and mid-latitude lower stratosphere, Science, 272, 1763-1768, 1996.

Vomel, H, Oltmans, S. J., Kley, D., and Crutzen, P.: New evidence for the stratospheric dehydration mechanism in the equatorial Pacific, Geophys. Res. Lett., 22, 3235-3238, 1995.

Waco, D. E.: Temperatures and turbolence at tropopause levels over hurricane Beulah (1967), Mon. Weather Rev., 98, 749-755, 1970.

Wang, P. K.: Moisture plumes above thunderstorm anvils and their contributions to cross-tropopause transport of water vapor in midlatitudes, J. Geophys. Res., 108(D6), 4194, doi:10.1029/2002JD002581, 2003.
Yushkov, V., Oulanovsky, A., Lechenuk, N., Rudakov, I., Arshinov, K., Tikhonov, F., Stefanutti, L., Ravegnani, F., Bonafe, U., and Georgiadis, T.: Achemilumineschent Analyser for stratospheric Measurements of the Ozone Concentration (FOZAN), J. Atmos. Oc. Tech., 16, 1345-1350, 1999.

Yushkov, V., Merkulov, S., and Astakhov, V.: Optical balloon hygrometer for upper stratosphere and stratosphere water vapor measurements, in: Optical remote sensing of the atmosphere and clouds, edited by: Wang, J., Wu, B., Ogawa, T., Guans, Z.-H., Proc. SPIE, 3501, 439-445, 1998.

Zou, X. and Wu, Y: On the relationship between Total Ozone Mapping Spectrometer (TOMS) ozone and hurricanes, J. Geophys. Res. 110, D06109, doi:10.1029/2004JD005019, 2005. 